\title{
Phytotoxin Produced by Bipolaris euphorbiae in-vitro is Effective Against the Weed Euphorbia heterophylla
}

\author{
Aneli M. Barbosa ${ }^{1 *}$; Cristina G. M. Souza ${ }^{1,2}$; Robert F. H. Dekker ${ }^{3}$; Rafael C. Fonseca ${ }^{1}$ and \\ Dalva T. Ferreira ${ }^{4}$ \\ Departamentos de: ${ }^{1}$ Bioquímica; ${ }^{3}$ Tecnologia de Alimentos e Medicamentos; $e^{4}$ Química; Universidade Estadual \\ de Londrina; Londrina - PR - Brazil. ${ }^{2}$ Presently at: Departamento de Bioquímica; Universidade Estadual de \\ Maringá; Maringá - PR - Brazil
}

\begin{abstract}
Four virulent strain isolates of the fungus, Bipolaris euphorbiae (previously identified as a Helminthosporium sp.), isolated from host plants in four states within Brazil were screened for the production of phytotoxins that promoted wilting and defoliation of the Brazilian weed, Euphorbia heterophylla, commonly found growing among soyabean crops. Only one isolate, B. euphorbiae Strain I (EUPH petropar from Mato Grosso state), produced phytotoxin invitro when grown in stationary culture for $7 \mathrm{~d}$ at $28{ }^{\circ} \mathrm{C}$ on minimum salts medium supplemented with $1.5 \%$ glucose as the sole carbon source. Phytotoxin was also produced when the fungal strain was grown on fructose, galactose, mannose, xylose and sucrose. The addition of nitrogen source (yeast extract, peptone or malt extract) to the culture medium did not influence phytotoxin production. The phytotoxin produced by Strain I was most active at pH 6.0, stable between $\mathrm{pH} 3-9$, and was highly thermostable, remaining fully active when heated at $90^{\circ} \mathrm{C}$ for $1 \mathrm{~h}$.
\end{abstract}

Key words: Bipolaris euphorbiae, Euphorbia heterophylla, phytotoxin production, phytotoxin stability

\section{INTRODUCTION}

The milk weed, or wild poinsettia, Euphorbia heterophylla is widely distributed throughout Brazil and infests up to 200,000 ha of cultivated soyabean (Glycine $\max \mathrm{L}$ ) land in the southern soyabean-growing states (Yorinori and Gazziero, 1989). The weed is difficult to control and herbicides that are effective against $E$. heterophylla can be expensive, as more than one application is frequently required during a crop season. The need for better control measures has led to a search for alternative methods to limit this weed's distribution. Biocontrol agents have potential and often synthesise phytotoxins that produce one or more specific disease symptoms in host plants when infected. Phytotoxins can elicit symptoms such as chlorosis, growth abnormalities, necrosis and wilting. The exact mechanisms by which this occurs is still not fully understood, but is thought to involve complex biochemical changes within the host plant (Harborne, 1993).

The phytopathogenic fungus, Bipolaris euphorbiae previously identified as a Helminthosporium species), is the causal agent for the major disease of E. heterophylla within Brazil (Barreto and Evans, 1998), and has been reported to be highly efficient and promising as a biological

\footnotetext{
* Author for correspondence
} 
control agent for this weed; as efficient as the best post-emergence herbicides (Yorinori, 1985; Yorinori and Gazziero, 1989). This microorganism produces host-specific phytotoxin(s) that elicits its effect during germination, and affects the leaves of susceptible E. heterophylla plants causing defoliation, but does not affect soybeans. Many fungal species pathogenic to agricultural crops of economic importance are known to produce phytotoxins. For example, those produced by the genus Helminthosporium have been shown to belong to several classes of natural products, e.g., macrocyclic peptides, polyketides, quinones, anthraquinones, and the free and glycosidic form of terpenes, phenols and flavonoids (Santos, 1997). An isolated toxin from Helminthosporium sacchari when applied to host-specific sugarcane plants, caused disease symptoms similar to those produced by the fungus (Steiner and Byther, 1971). The phytotoxins produced by Bipolaris species generally belong to a group of sesterpenoids called ophiobolins (tricyclic 5-8-5 ring systems) and have recently been reviewed by $\mathrm{Au}$ et al., (2000). Another related species, B. cynodontis, however, produced phytotoxins that belonged to a different group called cochlioquinones (Lim et al., 1998). The phytotoxin(s) from B. euphorbiae have not yet been characterised, but are present in culture filtrates of the fungus (Ferreira et al., 1987).

The program on the biological control of $E$. heterophylla by $B$. euphorbiae in soybean cultivation commenced at EMBRAPA, Londrina, Paraná, Brazil, in 1980 by Dr. J.T. Yorinori of National Centre of Soybean Research. The work reported here is an extension of those studies and concerns the examination of phytotoxin production in-vitro by four virulent strains of $B$. euphorbiae isolated from E. heterophylla plants found growing within four states of Brazil. We furthermore report on the production of phytotoxin(s) in one of those isolates ( $B$. euphorbiae Strain I: EUPH petropar) when cultured on simple nutrient medium, and comment on the effect of some cultivation parameters and properties of the phytotoxin itself.

\section{MATERIALS AND METHODS}

Virulent strains of the fungus, Bipolaris euphorbiae, were isolated from Euphorbia heterophylla leaves collected in four states of Brazil: Mato Grosso (Strain I: EUPH petropar), Mato Grosso do Sul (Strain II: EUPH fc bom), Paraná (Strain III: a sporulating mutant), and Rio Grande do Sul (Strain IV: HEM C95 A). All of the isolates of the above strains were kindly provided by Dr. J.T. Yorinori of EMBRAPA, Londrina, Paraná, Brazil. The fungi were maintained at $4{ }^{\circ} \mathrm{C}$ on potato-dextrose agar (PDA) slants, and subcultured at intervals of 1 - 4 months.

Inoculum was prepared by growing the fungal strains on PDA at $28 \pm 0.2{ }^{\circ} \mathrm{C}$ for 7 days, and using plugs of $13 \mathrm{~mm}$ diameter colonized with mycelium. Three plugs were used as inoculum per flask containing $50 \mathrm{ml}$ of culture medium.

The $B$. euphorbiae strains were grown in $250 \mathrm{ml}$ Erlenmeyer flasks containing $50 \mathrm{ml}$ basal medium (Vogel minimum salts medium (Vogel, 1956) with glucose as carbon source). Glucose and the salts solutions were separately sterilized $\left(121^{\circ} \mathrm{C}, 20\right.$ $\mathrm{min}$ ), and combined to bring the final glucose concentration in the basal medium to either 5,15 , 20 or $30 \mathrm{~g} \mathrm{l}^{-1}$. After inoculation, the flasks were incubated at $28 \pm 2{ }^{\circ} \mathrm{C}$ either in a rotary shaker $\left(180 \mathrm{rev} \mathrm{min}^{-1}\right)$, or in a stationary incubator, for 7 days. B. euphorbiae Strain I was also grown on a large scale in 21 Erlenmeyer flasks containing 400 $\mathrm{ml}$ basal medium (glucose $15 \mathrm{~g} \mathrm{l}^{-1}$ ) under stationary conditions at $28 \pm 2{ }^{\circ} \mathrm{C}$ for 7 days. All experiments were carried out in triplicate, except for those determining the growth profile of the fungus (followed over a period of 13 days), which was performed in replicates of four. The reported data represent average values \pm SD. Flasks without inoculum were maintained in parallel with the growing cultures as controls. Experiments evaluating the influence of the air-to-medium ratio were conducted in flasks of $250 \mathrm{ml}$ capacity containing $25 \mathrm{ml}, 50 \mathrm{ml}$ and $100 \mathrm{ml}$ of basal medium (15 $\mathrm{g}^{-1}$ glucose). In experiments examining the effects of exogenous-added nitrogen, either yeast extract (Difco), malt extract (Difco) or bacteriological peptone (BioBras, Brazil), were added to the basal medium (15 $\mathrm{g} \mathrm{l}^{-1}$ glucose) at a concentration of $2 \mathrm{~g} \mathrm{l}^{-1}$. Potatodextrose medium (no added salts) was prepared from whole potato $(200 \mathrm{~g})$ boiled in water (1 l) for $1 \mathrm{~h}$, followed by mashing, and the contents strained through cotton gauze. Glucose was added to the filtrate at a final concentration of $15 \mathrm{~g}^{-1}$. 
Cell-free fluid (ECF) was recovered by centrifugation (480 x g for $10 \mathrm{~min}$ ) and the supernatant filtered and stored at $4{ }^{\circ} \mathrm{C}$. Total sugar was measured by the phenol-sulfuric acid method (Dubois et al., 1956). Reducing sugars were determined by the methods of Nelson (1944) and Somogyi (1945). Glucose was used as standard in both sugar determinations. Protein was determined by a modified Lowry method using bovine serum albumen as a standard (Hartree, 1972). Fungal biomass was determined gravimetrically after washing the recovered mycelium with isotonic saline, centrifuging and drying the mycelium to constant weight at $100{ }^{\circ} \mathrm{C}$. Mycelial weights were corrected for the agar plugs used as inoculum. All assays were conducted in triplicate and represent mean values $\pm \mathrm{SD}$.

Soybean plants, and E. heterophylla plants susceptible to virulent strains of $B$. euphorbiae, were cultivated in pots from germinating seeds in a greenhouse under lights with a $12 \mathrm{~h}$ on-off cycle. Biological assays for phytotoxin activity were conducted on the leaves of plants that were at least 25 days old. Bioassays were performed by applying ECF topically with the aid of a cotton swab to the leaves of susceptible E. heterophylla and soybean plants in the late afternoon. The plants were then covered with black plastic bags to facilitate the absorption of phytotoxin, and left overnight. Next morning the bags were removed, and observations recorded at 12, 24 and $96 \mathrm{~h}$ following application of the ECF. Appropriate dilutions of the ECF were made using distilled water to determine the potency of phytotoxin concentration on biological activity. In some experiments, freeze-dried ECF was used (ECF from B. euphorbiae Strain I was dialysed (cellophane membrane) against distilled water at room temperature for $24 \mathrm{~h}$, the water changed every $2 \mathrm{~h}$, and then lyophilised). A $2 \% \mathrm{w} / \mathrm{v}$ solution of the lyophilised powder was used in the bioassays.

Biological activity was scored numerically in arbitrary units: (-) negative, (+) positive; $(+1)$, when disease spots appeared on the leaves after 12 $\mathrm{h}$ and wilted after $24 \mathrm{~h}$; $(+2)$, when the leaves wilted after $12 \mathrm{~h}$ (highly positive) and thereafter resulted in defoliation.

Thermostability: A $2 \%(\mathrm{w} / \mathrm{v})$ solution of the lyophillized ECF in water was heated for 15,30 and $60 \mathrm{~min}$ at $50{ }^{\circ} \mathrm{C}$, and the solution cooled to room temperature prior to the bioassay as described above. In another experiment, the solutions containing phytotoxin were heated at 70 , 80,90 and $100{ }^{\circ} \mathrm{C}$ for $60 \mathrm{~min}$, cooled and assayed for biological activity. Evidence of biological activity was scored numerically in arbitrary units: (0), no observable changes on the leaves; (1), spots dispersed on the leaves; (2), dark spots on all the leaves; (3), partial wilting of the leaves with the presence of dark spots; and (4), leaves completely wilted and defoliated.

$\mathrm{pH}$ dependence on phytotoxin activity: A $4 \%$ $(w / v)$ aqueous solution of the lyophilised ECF was diluted 1:1 in buffer (McIlvaine's citrate-

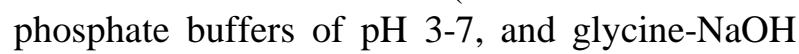
buffers of $\mathrm{pH}$ 8-12) to examine the effect of $\mathrm{pH}$ on phytotoxin activity. Freshly made buffered solutions containing the phytotoxin were assayed for biological activity, and scored numerically as outlined above. Appropriate solutions consisting of only buffer at each $\mathrm{pH}$ were diluted 1:1 with water and applied topically to E. heterophylla leaves as controls, and were assessed and scored in the same way as the ECF. Positive results from controls were deducted from the tests screening phytotoxin activity to correct for buffer interference. To determine the potency of the phytotoxin, the $2 \%$ buffered ECF solution, at each $\mathrm{pH}$ where there was a biological response, was diluted using deionized water to $1.0,0.5$, and $0.25 \%(\mathrm{w} / \mathrm{v})$ final ECF concentration, the $\mathrm{pH}$ adjusted where necessary, and further evaluated for biological activity.

\section{RESULTS AND DISCUSSION}

The four virulent $B$. euphorbiae strains used in this work grew on basal medium, but did not produce phytotoxin activity (Table 1) when cultivated in-vitro under submerged conditions as judged by the negative results for the bioassays on the leaves of susceptible E. heterophylla plants. Of the four fungal strains tested, only one, Strain I (EUPH petropar), produced phytotoxin activity indicating pathogenicity when cultivated under stationary conditions on basal medium (Table 1). In the field, all four strains of $B$. euphorbiae were host-specific disease-producing pathogens. The reason why the ECF of the other three fungal strains failed to produce biological responses 
could be explained twofold; the phytotoxin could be produced at low levels on the growth medium used that did not permit their detection (Pringle and Scheffer, 1967), and secondly, these strains could require specific components to induce the synthesis of phytotoxin, such as exist in the complex biochemical make-up of the host plant that determined these fungal strains to be hostspecific. For example, plants containing activators such as 2-amino-1,3-propanediol (serinol) produced in sugarcane leaves have been reported to induce phytotoxin production in attenuated strains of Helminthosporium sacchari (Pinkerton and Strobel, 1976). Additionally, we have observed that after successive transfers through long-term subculturing on PDA, B. euphorbiae Strain I lost the ability to produce phytotoxin invitro.

Table 1. The influence of submerged and stationary culture conditions on phytotoxin production by four strains of Bipolaris euphorbiae grown on basal medium containing $20 \mathrm{~g} \mathrm{l}^{-1}$ glucose.

\begin{tabular}{|c|c|c|c|c|c|c|}
\hline \multirow[t]{3}{*}{ Strains } & \multirow{2}{*}{\multicolumn{2}{|c|}{$\begin{array}{l}\text { Biomass } \\
\left(\mathrm{g} \mathrm{l}^{-1} \pm \mathrm{SD}\right)\end{array}$}} & \multirow{2}{*}{\multicolumn{2}{|c|}{$\begin{array}{l}\text { Residual sugars** } \\
\quad(\text { g l-1 } \pm \text { SD })\end{array}$}} & \multicolumn{2}{|c|}{ Biological assay $^{\#}$} \\
\hline & & & & & \multirow[t]{2}{*}{ SM } & \multirow[t]{2}{*}{ ST } \\
\hline & $\mathrm{SM}^{*}$ & $\mathrm{ST}^{+}$ & SM & ST & & \\
\hline \multirow[t]{2}{*}{ I } & 11.3 & 10.7 & 0.0 & 0.5 & \multirow[t]{2}{*}{$(-)$} & \multirow[t]{2}{*}{$(+)$} \\
\hline & \pm 0.84 & \pm 1.06 & & \pm 0.11 & & \\
\hline \multirow[t]{2}{*}{ II } & 8.0 & 7.2 & 1.3 & 6.5 & \multirow[t]{2}{*}{$(-)$} & \multirow[t]{2}{*}{$(-)$} \\
\hline & \pm 0.97 & \pm 1.91 & \pm 0.07 & \pm 0.16 & & \\
\hline \multirow[t]{2}{*}{ III } & 9.0 & 6.5 & 0.0 & 9.4 & \multirow[t]{2}{*}{$(-)$} & \multirow[t]{2}{*}{$(-)$} \\
\hline & \pm 1.01 & \pm 1.64 & & \pm 0.14 & & \\
\hline \multirow[t]{2}{*}{ IV } & 6.3 & 3.4 & 4.2 & 15.7 & \multirow[t]{2}{*}{$(-)$} & \multirow[t]{2}{*}{$(-)$} \\
\hline & \pm 0.98 & \pm 1.85 & \pm 0.16 & \pm 0.13 & & \\
\hline
\end{tabular}

* SM submerged, ${ }^{+}$ST stationary cultivation, $* *$ as reducing sugars, \# undiluted ECF

Phytotoxin activity, however, was restored when the strain was again grown on the leaves of susceptible E. heterophylla plants. This phenomenon has also been observed in $H$. sacchari (Pinkerton and Strobel, 1976). However, we didn't believe that reversion was the prime reason why the other $B$. euphorbiae strains failed to produce phytotoxin, as these isolates were demonstrated to be virulent when examined on susceptible E. heterophylla plants. Physiological factors were more likely to be responsible for lack of production of phytotoxin. The ECF from Strain I when applied to the leaves of soybean plants failed to cause any signs of disease (spotting or wilting) over a four-day period, demonstrating that the fungal phytotoxin did not affect soybean plants. It has been reported that fungal phytotoxins can also interact with other plants besides the host-specific plant (Hudson, 1986), however, this was not the case with $B$. euphorbiae. The phytotoxin of B. euphorbiae, furthermore, did not affect germination of soybean seeds, nor did it show any disease symptoms with plant development during growth. These results demonstrated that the phytotoxin produced by $B$. euphorbiae is specific for E. heterophylla, and indicates its suitability as a biocontrol agent of this weed when growing among soyabean crops. Field-grown soybean plants have similarly been shown not to be affected when treated with spores and live cultures of $B$. euphorbiae (Yorinori and Gazziero, 1989).

The glucose concentration in the medium was found to influence the production of phytotoxin by B. euphorbiae Strain I (Table 2). This is probably due to the production of more biomass by the growing fungal cells at the higher glucose levels, hence the cells can produce more phytotoxin. When these filtrates were diluted and assayed biologically, strong wilting of the leaves could be detected at dilutions of 1:20 for filtrates from the fungus grown on 15 and $30 \mathrm{~g} \mathrm{l}^{-1}$ glucose, but some spots on the leaves were still noticeable at 1:80 dilution. However, filtrates from cultures grown on basal medium containing $5 \mathrm{~g}^{-1}$ glucose registered a positive response only when undiluted.

The growth profile for B. euphorbiae Strain I on basal medium (15 $\mathrm{g} \mathrm{l}^{-1}$ glucose) over 13 days is shown in Figure 1. Maximum biomass was 
reached by day 6-7 which coincided with a drop in the $\mathrm{pH}$ to 4.2 . The maximum specific growth rate $\left(\mu_{\max }\right)$ over the first 5 days was 0.423 day $^{-1}$. The effect of inoculum concentration when doubled did not produce a lag phase nor more biomass. Nor did it result in higher phytotoxin activity being produced. However, when the inoculum was halved, a lag phase occurred, and proportionately less biomass and phytotoxin were produced. The bioassay results presented in (Figure 1) showed that phytotoxin production reached its maximum at 6-7 days growth coinciding with maximal mycelium production.

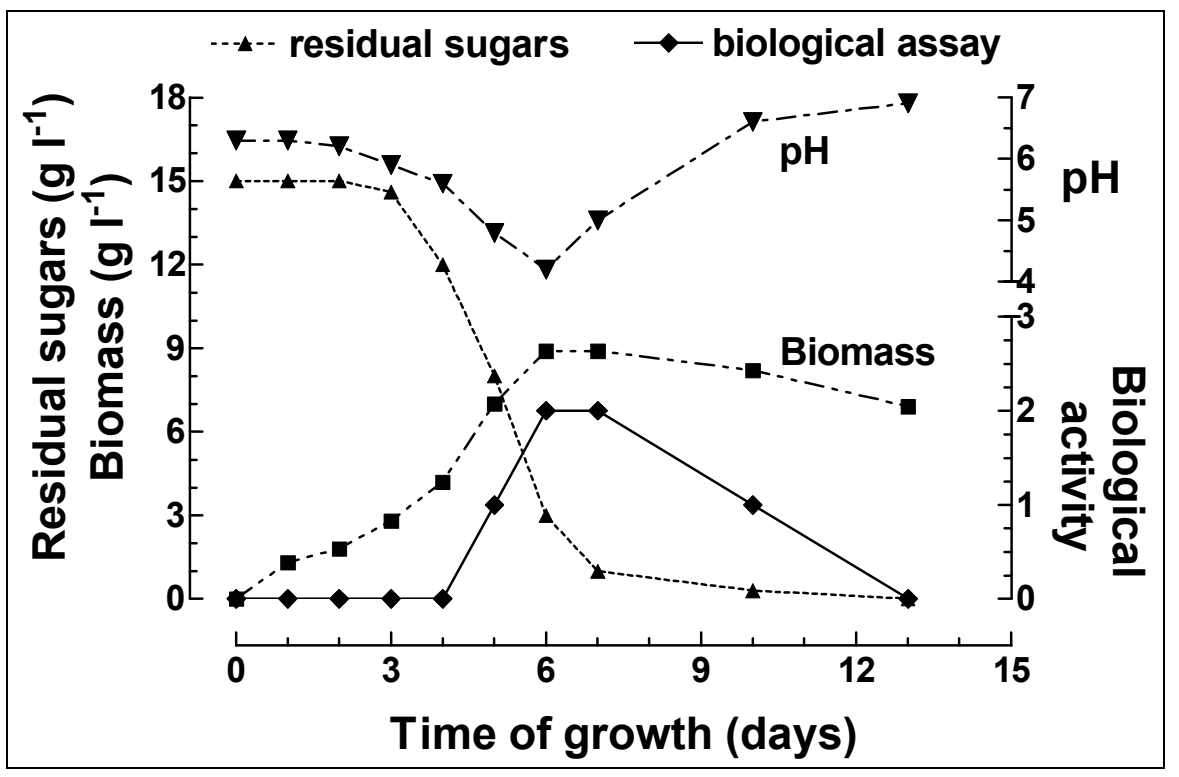

Figure 1 - Production of phytotoxin by Bipolaris euphorbiae Strain I (EUPH petropar) grown in stationary culture on basal medium containing $15 \mathrm{~g} \mathrm{l-1}$ glucose.

Thereafter both phytotoxin activity and mycelium concentration decreased, probably as a consequence of endogenous metabolism, as the sugar concentration in the medium at this stage was low $\left(0.8 \mathrm{~g} \mathrm{l}^{-1}\right)$. Furthermore, cell lysis was not observed during this period. Maximal production of phytotoxin towards the end of the growth phase has similarly been reported for H. victoriae (Luke and Wheeler, 1955), H. maydis (Smedegard and Nelson, 1969), and H. nodulosum (Vidhyasekaran, 1977).The air-to-nutrient medium ratio also influenced the production of phytotoxin by $B$. euphorbiae when grown under stationary conditions, and was maximal at 10:1, demonstrating that as the volume of air in the flasks decreased, this was accompanied by a corresponding decrease in glucose consumption, biomass and phytotoxin production. In this case, phytotoxin production appears to be related to the amount of mycelium produced, and this observation was further corroborated by the results correlating biomass levels with phytotoxin activity in Figure 1 and Table 2.

Glucose is commonly used as a carbon source by most fungi, including those producing phytotoxins. Fructose, mannose, galactose, xylose and sucrose can also serve as carbon sources, but require an adaptation phase as they must be phosphorylated prior to interconversion during glycolysis (Gadd, 1988). Xylose is metabolised via the pentose phosphate pathway, while sucrose must first be hydrolyzed to its constitutent sugars. $B$. euphorbiae grew equally well on each of the different sugar substrates studied, and produced phytotoxin (Table 3) in each case. Sugar consumption was similar (98\%) for all of the substrates, with the exception of galactose which was lower $(81 \%)$. Vidhyaskaren (1977) has also reported the production of phytotoxin in $H$. nodulosum when cultivated on similar sugars and starch. Fructose and sucrose, along with glucose, are common plant sugars produced by photosynthesis (Raven, Evert and Eichdorn, 1992), and can support growth of microorganisms 
including $B$. euphorbiae. The influence of an various nitrogen sources added to the basal medium had no effect on the production of phytotoxin by $B$. euphorbiae Strain 1 . When the ECF was diluted, the yeast extract-grown cultures lost phytotoxin activity, but the ECF from the other grown cultures, nonetheless, maintained their biological potency, even at dilutions of 1:20. The C:N ratio in the nitrogen-supplemented cultures was low (1.9 - 3.3) compared to the basal medium (8.6). A low $\mathrm{C}: \mathrm{N}$ ratio has similarly been found to support phytotoxin production in $H$. nodulosum (Vidhyasekaran, 1977). Potato-dextose medium could also serve as a suitable medium for the production of phytotoxin by B. euphorbiae Strain I.

There did not appear to be any correlation between phytotoxin concentration and phytotoxin activity when a solution of lyophilised ECF was applied topically to the leaves of E. heterophylla. The reason for this may be governed by how well the applied ECF was absorbed and diffused into the surrounding tissues in the leaves to manifest a pathogenic response. A $2 \%$ solution of the freezedried ECF was therefore selected in studies examining the influence of temperature and $\mathrm{pH}$ on biological activity.

Table 2 - The effect of glucose concentration on phytotoxin activity and biomass production by Bipolaris euphorbiae Strain I after seven days under stationary culture conditions

\begin{tabular}{ccccc}
\hline $\begin{array}{c}\text { Glucose } \\
\left(\mathrm{g} \mathrm{l}^{-1}\right)\end{array}$ & $\begin{array}{c}\text { Biomass } \\
\left(\mathrm{g} \mathrm{l}^{-1} \pm \mathrm{SD}\right)\end{array}$ & $\begin{array}{c}\text { Residual sugars** } \\
\left(\mathrm{g} \mathrm{l}^{-1} \pm \mathrm{SD}\right)\end{array}$ & Final $\mathrm{pH}^{*}$ & $\begin{array}{c}\text { Biological } \\
\text { assay }\end{array}$ \\
\hline 5 & $5.0 \pm 1.56$ & 0 & 6.6 & $+1^{+}$ \\
15 & $9.6 \pm 1.28$ & $1.7 \pm 0.05$ & 4.8 & $+2^{\#}$ \\
30 & $12.6 \pm 0.72$ & $10.1 \pm 0.11$ & 4.6 & $+2^{\#}$ \\
\hline
\end{tabular}

initial pH 6.3, ${ }^{+}$undiluted ECF, ** as reducing sugars, ${ }^{\#}$ ECF diluted 1:20

Table 3 - The influence of carbon source on phytotoxin activity and biomass production by Bipolaris euphorbiae Strain I after seven days growth under stationary conditions.

\begin{tabular}{lcccc}
\hline Carbon source & $\begin{array}{c}\text { Biomass } \\
\left(\mathrm{g}^{-1} \pm \mathrm{SD}\right)\end{array}$ & $\begin{array}{c}\text { Sugar } \\
\text { Consumption } \\
(\%)^{+}\end{array}$ & $\begin{array}{c}\text { Final } \\
\mathrm{pH}^{*}\end{array}$ & $\begin{array}{c}\text { Biological } \\
\text { assay }^{\#}\end{array}$ \\
\hline Glucose & $10.0 \pm 0.84$ & 98 & 6.5 & +2 \\
Xylose & $8.4 \pm 1.78$ & 98 & 6.3 & +2 \\
Galactose & $9.7 \pm 1.56$ & 81 & 6.1 & +2 \\
Mannose & $9.8 \pm 1.21$ & 99 & 5.9 & +2 \\
Fructose & $9.0 \pm 1.46$ & 97 & 6.8 & +2 \\
Sucrose & $9.0 \pm 1.65$ & 98 & 6.9 & +2 \\
\hline++
\end{tabular}

The phytotoxin was stable when heated at $50{ }^{\circ} \mathrm{C}$ for up to $60 \mathrm{~min}$ losing no biological activity during this period. When the ECF was heated at temperatures up to $90{ }^{\circ} \mathrm{C}$ for $60 \mathrm{~min}$, there was no apparent loss of biological activity under the assay conditions. Heating at $100{ }^{\circ} \mathrm{C}$ for $1 \mathrm{~h}$, however, did result in a loss of about $25 \%$ of the initial activity of the phytotoxin, indicating that the phytotoxin produced by $B$. euphorbiae Strain I was highly thermostable. The toxin produced by Helminthosporium. nodulosum has also been shown to be stable up to $90{ }^{\circ} \mathrm{C}$, but lost total activity at $100{ }^{\circ} \mathrm{C}$ (Vidhyasekaran, 1977). The effect of $\mathrm{pH}$ on phytotoxin activity was studied using 2 buffer systems over a $\mathrm{pH}$ range of 3-12, and at different concentrations of ECF. It apperaed that $\mathrm{pH} 6.0$ was most effective in eliciting biological activity of the phytotoxin for all 
concentrations studied. This was within the range of the final $\mathrm{pH}$ of the culture medium following growth. The phytotoxin of $B$. euphorbiae was stable over a broad $\mathrm{pH}$ range (3-9). Comstock and Scheffer (1972) found that the phytotoxin produced by $H$. maydis was relatively stable at $\mathrm{pH}$ 3.5 when autoclaved $\left(121{ }^{\circ} \mathrm{C}\right.$ for $\left.15 \mathrm{~min}\right)$ and progressively lost activity when autoclaved at higher $\mathrm{pH}$ values. Similarly, the toxin from $H$. nodulosum was stable at $\mathrm{pH} \mathrm{3-7,} \mathrm{but} \mathrm{unstable}$ within the alkaline range (Vidhyasekaran, 1977), whereas the toxin from $H$. sativum was more stable at the alkaline range (Das and Srivastava, 1969).

Although the chemical structures of the phytotoxins produced by several species of Bipolaris are known (Au et al., 2000), that produced by $B$. euphorbiae Strain I has not yet been determined. Our studies, however, conclude that it's phytotoxin is unlikely to be protein by nature, as the extreme temperatures it was exposed to would lead to it's denaturation and hence, loss of biological activity.

\section{ACKNOWLEDGMENTS}

This work was supported by FINEP (Brazil) and PPG-UEL. C. Souza and R. Fonseca gratefully acknowledge CAPES and CNPq-PIBIC (Brazil) for providing scholarships at UEL. The authors are grateful to Dr. J.T. Yorinori of EMPRABA, Londrina, PR, Brazil, for providing the strain isolates of Bipolaris euphorbiae, and Euphorbia heterophylla seeds and plants. Erico Damineli is thanked for experimental assistance.

\section{RESUMO}

Quatro linhagens virulentas do fungo Bipolaris euphorbiae (previamente identificado como Helminthosporium sp.), isoladas de Euphorbia heterophylla de quatro estados do Brasil, foram estudadas quanto a produção de fitotoxina, que promove murcha e desfolha da referida erva daninha brasileira, popularmente denominada leiteiro e comumente encontrada nas culturas de soja. O isolado Bipolaris euphorbiae linhagem I (EUPH petropar do estado de Mato Grosso), produziu fitotoxina in-vitro quando cultivada sob condição estática, durante 7 dias, a $28{ }^{\circ} \mathrm{C}$ em meio mínimo suplementado com glucose $1,5 \%$, como fonte única de carbono. A fitotoxina foi também produzida quando o isolado foi cultivado em frutose, galactose, manose, xilose e sacarose. A adição de fonte de nitrogênio (extrato de levedura, peptona e extrato de malte) ao meio de cultivo não influenciou a produção da mesma. A fitotoxina produzida pela linhagem I apresentou maior atividade em $\mathrm{pH} \mathrm{6,0}$, permaneceu estável na faixa de $\mathrm{pH}$ entre 3 e 9 e demonstrou elevada termoestabilidade, mantendo-se ativa após ter sido aquecida durante uma hora a $90{ }^{\circ} \mathrm{C}$.

\section{REFERENCES}

Au, T. K., Chick, W. S. H. and Leung, P. C. (2000), The biology of ophiobolins. Life Sciences, 67, 733-742.

Barreto, R. W. and Evans, H. C. (1998), Fungal pathogens of Euphorbia heterophylla and E. hirta in Brazil and their potential as weed biocontrol agents. Mycopathologia, 141, 21-36.

Comstock, J. C. and Scheffer, R. P. (1972), Production and relative host-specificity of a toxin from Helminthosporium maydis race T. Plant Disease Reporter, 56, 247-251.

Das, A. M. and Srivastava, D. N. (1969), Production and action of wheat seedlings of toxic metabolites of Helminthosporium sativum. Annals of the Phytopathological Society of Japan, 35, 275-281.

Dubois, M., Gilles, K. A., Hamilton, J. K., Rebers, P. A. and Smith, F. (1956), Colorimetric method for the determination of sugars and related substances. Analytical Chemistry, 28, 350-356.

Ferreira, D. T., Perez, C. A. S., Andrei, C. C., Pedrotti, F., Faccione, M., Gallon, O. F. and Yorinori, J. T. (1987), Fitotoxina produzida pelo fungo Helminthosporium $s p$. Paper presented at 39. Reunião Anual da Sociedade Brasileira para o Progresso da Ciência. Brasília: SBPC. pp. 509.

Gadd, G. M. (1988), Carbon nutrition and metabolism. In - Berry, D. R. (ed.). Physiology of Industrial Fungi. Oxford : Blackwell Scientific Publications. pp. 21-57.

Harborne, J. B. (1993), Introduction to Ecological Biochemistry, 4th edn, pp. 264-297. Academic Press, New York.

Hartree, E. F. (1972), Determination of protein: a modification of the Lowry method that gives a linear photometric response. Analytical Biochemistry, 48, 422-427.

Hudson, H. J. (1986), Fungi as parasitic symbionts of 
plants. In - Fungal Biology. Edward Arnold. London. pp. 262-276.

Lim, C. H., Miyagawa, H., Akamatsu, M., Nakagawa, Y. and Ueno, T. (1998), Structures and biological activities of phytotoxins produced by the plant pathogenic fungus Bipolaris cynodontis cynA. Journal of Pesticide Science, 23, 281-288.

Luke, H. H. and Wheeler, H. E. (1955), Toxin production by Helminthosporium victoriae. Phytotpathology, 45, 453-458.

Nelson, N. (1944), A photometric adaptation of the Somogyi method for determination of glucose. Journal of Biological Chemistry, 153, 375-380.

Pinkerton, F. and Strobel, G. (1976), Serinol as an activator of toxin production in attentuated cultures of Helminthosporium sacchari. Proceedings National Academy of Sciences (USA), 73, 4007-4011.

Pringle, R. B. and Scheffer, R. P. (1967), Isolation of the host-specific toxin and a related substance with nonspecific toxity from Helminthosporium carbonum. Phytopathology, 57, 1169-1172.

Raven, P. H., Evert, R. F. and Eichdorn, S. E. (1992), Biology of Plants. New York : Worths Publishers. pp.99-119.

Santos, R. M. (1997), Helminthosporium. Monografia: Curso de Especialização em Química. Londrina: Departamento de Química, Universidade Estadual de Londrina, Brazil. pp. 1-44.

Smedegard, P. V. and Nelson, R. R. (1969), A hostspecific toxin produced by certain isolates of Helminthosporium maydis. Phytopathology, 59, 402.

Somogyi, M. (1945), A new reagent for the determination of sugars. Journal of Biological Chemistry, 160, 61-68.

Steiner, G. W. and Byther, R. S. (1971), Partial0 characterization and use of a host-specific toxin from Helminthosporium sacchari on sugarcane. Phytopathology, 61, 691-695.
Vidhyasekaran, P. (1977), Toxin production by Helminthosporium nodulosum. Indian Phytopathology, 30, 473-478.

Vogel, H. J. (1956), A convenient growth medium for Neurospora crassa. Genetic Bulletin, 13, 42-43.

Yorinori, J. T. (1985), Biological control of milk weed (Euphorbia heterophylla) with pathogenic fungi. In Delfosse, E. S. (ed.). Proceedings 6th International Symposium on Biological Control of Weeds, $19-$ 25 August, 1984, Vancouver, Canada. Ottawa : Agriculture Canada. pp. 677-681.

Yorinori, J. T. and Gazziero, L. P. (1989), Control of milk weed (Euphorbia heterophylla) with Helminthosporium sp. In - Delfosse, E. S. (ed.). Proceedings 7th International Symposium on Biological Control of Weeds, 6-11 March, 1988, Rome, Italy. Sper. Patol. Veg. (MAF). pp. 571-576.

Received: October 25, 2000; Revised: January 29, 2001; Accepted: June 25, 2001. 